\title{
Spatial distribution and rate of potential nitrification activity in two hill country pastures
}

\author{
S.A. LETICA ${ }^{1,2}$, R. TILLMAN ${ }^{2}$, R. LITTLEJOHN ${ }^{1}$, C.J. HOOGENDOORN ${ }^{3}$, C.A.M DE KLEIN ${ }^{1}$ and P. KEMP ${ }^{2}$ \\ ${ }^{1}$ AgResearch, Invermay Research Centre, PB 50034, Mosgiel \\ ${ }^{2}$ Massey University, Institute of Natural Resources, PO Box 11 222, Palmerston North \\ ${ }^{3}$ AgResearch, Grasslands Research Centre, PB 11 008, Palmerston North \\ selai.letica@agresearch.co.nz
}

\begin{abstract}
The purpose of this study was to conduct a preliminary investigation into the effect of increasing fertiliser- and excreta-N inputs on the spatial distribution and rate of potential nitrification activity in hill country pasture land at two sites, Invermay and Ballantrae. High nitrification rates could potentially limit $\mathrm{N}$ efficiency by increasing $\mathrm{N}$ losses through leaching and denitrification. Nitrification potentials (NP) were measured in camp sites and medium slopes of hill country soils receiving $0 \mathrm{~kg} \mathrm{~N}$ and $500 \mathrm{~kg}$ $\mathrm{N} / \mathrm{ha} / \mathrm{yr}$ over the previous 18 months. Nitrification potential was determined by calculating the rate of nitrate production ( $\mathrm{mg} \mathrm{NO}_{3}-\mathrm{N} / \mathrm{kg}$ soil $/ \mathrm{h}$ ) by linear regression of soil solution concentrations, versus time. Nitrification potential was significantly higher at Invermay than at Ballantrae, which was likely due to a significantly lower soil $\mathrm{pH}$ at Ballantrae. At Invermay, NP increased with fertiliser-N application rate and in camp site soils. The fertiliser $\mathrm{N}$ effect was not observed at Ballantrae. However, soil $\mathrm{NO}_{3}-\mathrm{N}$ and $\mathrm{NP}$ was significantly greater in soils from camp sites than for soils from medium slopes. Best management practices for fertiliser- $\mathrm{N}$ application in hill country should make allowances for these factors to maximise farm efficiency and profitability. Keywords: hill country, nitrification potential, nitrogen fertiliser, stock behaviour, excreta-N, mineral-N, New Zealand
\end{abstract}

\section{Introduction}

Conventional hill country pasture management has largely relied on superphosphate, sulphur, or lime applications (Ball et al. 1982). Such soil amendments aid establishment and continued survival of legume species (primarily Trifolium repens) that supply hill soils with mineral-N (Morton et al. 1993). However, even if all other major and trace element requirements are met, plant available $\mathrm{N}$ will always remain deficient due in part to the transfer of nutrient- $\mathrm{N}$ from slopes to flat campsites in the excreta of grazing animals (Ball et al. 1982). From the early 1980s, fertiliser $\mathrm{N}$ trials in hill country have reported annual response efficiencies that range from 7 to $42 \mathrm{~kg} \mathrm{DM} / \mathrm{kg}$ $\mathrm{N}$. Fertiliser $\mathrm{N}$ application rates that yielded these responses ranged from 50 to $400 \mathrm{~kg} \mathrm{~N} / \mathrm{ha} / \mathrm{yr}$, following various split application regimes across seasons (Ball et al. 1982; Hoogendoorn 2006; Lambert et al. 2003; Stevens 2006). In response to this, and to a favourable relationship between the cost of fertiliser $\mathrm{N}$ plus application and farm product prices, typical applications rose almost ten-fold from 1996 to 2002 (Hoogendoorn 2006).

To manage the increased pasture production due to increased fertiliser- $\mathrm{N}$ application, stocking rates are usually increased to profitably utilise extra forage and maintain pasture quality. The increase in stock density results in an increase in excreta-N return to soils (Steenvoorden et al. 1986; Whitehead 1995). The return of excreta-N becomes increasingly non-uniform as topographical (i.e. slope class) variation increases within hill country pastures (Ball et al. 1982). Up to $60 \%$ of dung and $55 \%$ of urine may be deposited on campsite and track areas that occupy only $15-31 \%$ of a hill country land unit (Saggar et al. 2004; Sakadevan et al. 1993). Consequently a net accumulation of $\mathrm{N}$ occurs on flatter camp and track sites, and net depletion occurs on the steeper slopes where animals graze but do not camp (Bowatte 2003; López et al. 2003; Radcliffe 1982). However, there is little quantitative information regarding the fate of fertiliser- or excreta- $\mathrm{N}$ to microbial processes in hill country pastures (Bowatte 2003; Carran et al. 1995).

The microbial oxidation of $\mathrm{NH}_{4}-\mathrm{N}$ from urine and urea to $\mathrm{NO}_{3}-\mathrm{N}$ (nitrification) is of considerable importance to the fate of fertiliser- and excreta- $\mathrm{N}$, because of the potential to increase $\mathrm{NO}_{3}$ - pollution through leaching and denitrification (Fair et al. 1994). These losses are important from both environmental and farm production standpoints. Nitrifying bacteria most commonly occur where favourable soil and climatic conditions prevail, and tend to be most active (i.e. oxidise $\mathrm{NH}_{4}-\mathrm{N}$ faster) at these sites (Haynes 1986). Once the supply of $\mathrm{NO}_{3}-\mathrm{N}$ to plants exceeds demand, excess $\mathrm{NO}_{3}-\mathrm{N}$ may be lost to the environment. Trials have demonstrated that significant losses of $\mathrm{NO}_{3}-\mathrm{N}$ due to leaching and denitrification occur under urine patches in both high and low N soils (de Klein \& van Logtestijn 1994; Di \& Cameron 2002; Field et al. 1985; Haynes \& Williams 1992).

The present study aimed to determine if the nitrification 
potential (NP) rates in hill country soils are affected by an increase in fertiliser- $\mathrm{N}$ and subsequent increases in excreta-N, by comparing NP in sheep-grazed plots treated with 0 or $500 \mathrm{~kg} \mathrm{~N}$ fertiliser. The working hypothesis was that NP would be higher in plots receiving the high rate of fertiliser- $\mathrm{N}$ compared to plots receiving no fertiliser- $\mathrm{N}$, due to increased $\mathrm{NH}_{4}-\mathrm{N}$ availability. We also hypothesised that NP would be higher in low slope soils (i.e. camp sites), when compared to that measured in medium slope soils due to the regular addition of $\mathrm{NH}_{4}-\mathrm{N}$ via excreta to campsites.

\section{Methods}

\section{Field sites}

The experiment was established on two AgResearch hill country farms, one in the South Island (Invermay, Mosgiel) and one in the North Island (Ballantrae, Woodville).

The Invermay experimental site is situated c. $100-$ $200 \mathrm{~m}$ a.s.l. and receives an average annual rainfall of 700 to $750 \mathrm{~mm}$ (Otago Regional Council 2006). The predominant soil type is a Warepa silt loam (Mottled Fragic Pallic soil), situated on rolling land (c. 8 to $15^{\circ}$ Hewitt 1998). The Ballantrae Research Farm is $c .200$ to $350 \mathrm{~m}$ a.s.l. and receives an average rainfall of $1270 \mathrm{~mm}$ annually (summer moist steep hill country). The predominant soil types are classified as Brown soils (i.e. yellow-brown earths and intergrades to yellow-grey earths, and related steepland soils, (Hewitt 1998), on heavily dissected hill country (

\section{Field trial design}

In February 2006 nitrification potential was measured in sheep grazed plots that had received 0 or $500 \mathrm{~kg} \mathrm{~N} / \mathrm{ha} / \mathrm{yr}$ since September 2004. There were three replicated paddocks for each treatment, except for the $500 \mathrm{~kg} \mathrm{~N}$ treatment at Ballantrae, which was in duplicate paddocks. The last fertiliser application prior to this study was December 2005 (62.5 kg N/ha) on Invermay Farm and January 2006 (83 kg N/ha) on Ballantrae Farm. The current experiment was a split plot design with $\mathrm{N}$ treatments as the main plots. Within each plot, six subplots were established: three low slope subplots $\left(0\right.$ to $12^{\circ}$, LS) and three medium slope subplots ( 13 to $\left.25^{\circ}, \mathrm{MS}\right)$. Soil cores were taken within a $5 \mathrm{~h}$ period and the number of dung deposits within a $30 \mathrm{~cm}$ radius of the sample site was recorded as an indicator of camping behaviour. Within each subplot, six soil cores $(25 \times 75 \mathrm{~mm})$ were removed and chilled.

In the laboratory the six cores from each subplot were bulked, sieved $(2 \mathrm{~mm})$ and then split into duplicate samples. One sample duplicate was used for mineral $\mathrm{N}$ extraction $(2 \mathrm{M} \mathrm{KCl})$, soil $\mathrm{pH}$, and the determination of soil moisture content (Hatch et al. 2000). The second duplicate was used for NP measurements (Hart et al. 1994).

Nitrification potential assesses the maximum rate of nitrification $(V \max )$ or potential nitrification activity. Samples were optimised with respect to water content, $\mathrm{NH}_{4}-\mathrm{N}\left(1.5 \mathrm{mM} \mathrm{NH}_{4}^{+}\right)$, P-availability $\left(1 \mathrm{mM} \mathrm{PO}_{4}^{3}\right)$, and aeration. The NPs were determined by calculating the rate of $\mathrm{NO}_{3}-\mathrm{N}$ production $(\mathrm{mg} / \mathrm{kg}$ dry soil $/ \mathrm{h}$ ) by linear regression of solution concentrations, versus sample time (2, 4, 22, and 24 h, as in Hart et al. (1994).

\section{Statistical Methods}

Soil mineral-N data $\left(\mathrm{NH}_{4}-\mathrm{N}\right.$ and $\left.\mathrm{NO}_{3}-\mathrm{N}\right)$ were analysed using a gamma-log generalised linear mixed model (Schall 1991). Site description data $(\mathrm{pH}$, soil moisture and dung counts) were analysed by analysis of variance (ANOVA). The block structure was given by location within pair within paddock. The treatment structure was by site, $\mathrm{N}$ treatment and slope, and all interactions involving these terms. For the calculation of NP rate, data points that were below detection limits $(<0.25 \mathrm{ppm})$ were deleted and substitute values (between 0 and 0.25 ) were calculated and used in the ANOVA (Taylor 1973). Nitrification potential data were analysed by ANOVA. The block structure was given by duplicate within location, within pair, within paddock. The treatment structure was by $\mathrm{N}$ treatment, and slope, and their interaction. All analyses were done using the statistical package GenStat (2006).

\section{Results and Discussion}

At Invermay NP was significantly greater at the higher $\mathrm{N}$ fertiliser application rate $(\mathrm{P}<0.05)$, and in low slopes (i.e. camp sites) compared to medium slopes $(\mathrm{P}<0.01$, Table 1). At Ballantrae, NP was significantly higher in low slopes than in medium slopes $(\mathrm{P}<0.01)$, but there was not a significant effect of $\mathrm{N}$ fertiliser on NP. Overall, $\mathrm{NP}$ rates were significantly higher at Invermay than at Ballantrae $(\mathrm{P}<0.01)$, with mean NP ranging from 0.65 to $3.45 \mathrm{mg} \mathrm{NO}-\mathrm{N} / \mathrm{kg}$ soil $/ \mathrm{h}$ at Invermay, and 0.26 to $1.15 \mathrm{mg} \mathrm{NO}_{3}-\mathrm{N} / \mathrm{kg}$ soil $/ \mathrm{h}$ at Ballantrae. Nitrification rates in previous comparable studies (Sarathchandra et al. 1984; Steele et al. 1980) ranged from $<0.02$ to $0.47 \mu \mathrm{g} /$ $\mathrm{g}$ soil/h for yellow-brown earths and 0.08 to $0.76 \mu \mathrm{g} / \mathrm{g}$ soil/h for yellow-grey earths. These were similar to the soils in the current study. Mean NP for both soil types was greater in the present study, which may be due to the higher fertiliser-N treatment and higher stocking rates (hence high excretal-N) in our study.

The observed higher NP rates at Invermay compared to Ballantrae may be due to significant differences in soil pH (Ballantrae 5.3 and Invermay 6.1; Table 2). Low pH can significantly inhibit soil microbial activity and the rate of soil $\mathrm{C}$ and $\mathrm{N}$ cycling (Kemmit et al. 2006; 
Table 1 Rate of potential nitrification ( $\mathrm{mg} \mathrm{NO}_{3}-\mathrm{N} / \mathrm{kg}$ dry soil/h) in soil incubations from low and medium slopes receiving 0 and $500 \mathrm{~kg} \mathrm{~N} / \mathrm{ha} / \mathrm{yr}$ on Invermay and Ballantrae hill country farms.

\begin{tabular}{lccc}
\hline Slope & N rate $(\mathrm{kg} / \mathrm{ha} / \mathrm{yr})$ & Ballantrae & Invermay \\
\hline Low & 0 & 1.15 & 1.46 \\
Low & 500 & 0.94 & 3.45 \\
Medium & 0 & 0.36 & 0.65 \\
Medium & 500 & 0.26 & 2.46 \\
SED & & 0.488 & 0.562 \\
Significance (slope) & & $* *$ & $*$ \\
Significance (N rate) & & $\mathrm{ns}$ & $*$ \\
\hline
\end{tabular}

Table 2 Soil $\mathrm{pH}$ at Ballantrae compared to Invermay hill country farm trial sites. Differences are significant, $\mathrm{P}<0.001$.

\begin{tabular}{lccc}
\hline Slope & N rate $(\mathrm{kg} / \mathrm{ha} / \mathrm{yr})$ & Ballantrae & Invermay \\
\hline Low & 0 & 5.4 & 6.1 \\
Low & 500 & 5.4 & 6.0 \\
Medium & 0 & 5.1 & 6.1 \\
Medium & 500 & 5.3 & 6.1 \\
Site mean & & 5.3 & 6.1 \\
SED & & & 0.15 \\
\hline
\end{tabular}

Table 3 Soil mineral-N concentrations ( $\mathrm{mg} / \mathrm{kg}$ dry soil) in Ballantrae and Invermay hill country soils from low (LS) and medium (MS) slopes in 0 and $500 \mathrm{~kg} \mathrm{~N}$ treatment plots.

\begin{tabular}{|c|c|c|c|c|}
\hline & Slope & $\mathrm{N}$ rate $(\mathrm{kg} / \mathrm{ha} / \mathrm{yr})$ & Ballantrae & Invermay \\
\hline \multirow{7}{*}{$\mathrm{NH}_{4}-\mathrm{N}$} & Low & 0 & 21.9 & 5.1 \\
\hline & Low & 500 & 37.7 & 11.1 \\
\hline & Medium & 0 & 22.9 & 4.9 \\
\hline & Medium & 500 & 32.7 & 15.8 \\
\hline & SED & & 17.1 & 4.8 \\
\hline & Significar & & ns & ns \\
\hline & Significar & te) & ns & * \\
\hline \multicolumn{5}{|l|}{$\mathrm{NO}_{3}-\mathrm{N}$} \\
\hline & Low & 0 & 60.7 & 11.5 \\
\hline & Low & 500 & 95.6 & 70.0 \\
\hline & Medium & 0 & 30.3 & 8.8 \\
\hline & Medium & 500 & 51.4 & 66.1 \\
\hline & SED & & 37.2 & 30.1 \\
\hline & Significar & & $* *$ & ns \\
\hline & Significan & te) & ns & $\star *$ \\
\hline
\end{tabular}

Table 4 Number of dung deposits on low and medium slopes at Ballantrae and Invermay hill country farms. Differences are significant, $\mathrm{P}<0.01$.

\begin{tabular}{lccc}
\hline Slope & $\mathrm{N}$ rate $(\mathrm{kg} / \mathrm{ha} / \mathrm{yr})$ & Ballantrae & Invermay \\
\hline Low & 0 & 2.1 & 1 \\
Low & 500 & 2.2 & 2.2 \\
Medium & 0 & 0.8 & 0.9 \\
Medium & 500 & 1.7 & 0.3 \\
SED & & & 0.35 \\
\hline
\end{tabular}

Sarathchandra 1978). Steele et al. (1980) found for similar New Zealand soils that $\mathrm{pH}$, organic $\mathrm{C}$, total $\mathrm{N}$, and $\mathrm{C} / \mathrm{N}$ ratio were related to the rate of initial nitrification activity $\left(\mathrm{R}^{2}=0.44\right.$. Excludes soils of $\mathrm{pH}>7$ and yellow-brown loams); and that when the $\mathrm{pH}$ was raised, nitrification increased. Sarathchandra (1978) also found that an increase in soil $\mathrm{pH}$ in acid soils resulted in an improved nitrification rate. Work from Bowatte (2003), Lambert et al. (1982) and Sakadevan (1993) also reported delayed or slow rates of nitrification in North Island hill country soils. It is difficult to draw conclusions about the effect of soil pH on NP based on the current data set. However, the fact that soil $\mathrm{pH}$ and NP were significantly lower at Ballantrae is consistent with previous results.

The difference in NP observed between slope and treatment was supported by the soil mineral-N $\left(\mathrm{NO}_{3}-\right.$ 
and $\mathrm{NH}_{4}-\mathrm{N}$ ) measurements (Table 3). At Invermay, soil $\mathrm{NO}_{3}-\mathrm{N}$ concentrations were significantly greater for the $500 \mathrm{~kg} \mathrm{~N}$ treatment than for $0 \mathrm{~kg} \mathrm{~N}$ (mean $=68.1 \mathrm{cf} .10 .2$ $\mathrm{mg} / \mathrm{kg}$ soil, $\mathrm{P}<0.001)$. Values for $\mathrm{NH}_{4}-\mathrm{N}$ in the $500 \mathrm{~kg}$ $\mathrm{N}$ were also significantly greater than in the $0 \mathrm{~kg} \mathrm{~N}$ treatment $($ mean $=13.5 \mathrm{cf} .5 .0 \mathrm{mg} / \mathrm{kg}$ soil, $\mathrm{P}<0.05)$. At Ballantrae average $\mathrm{NO}_{3}-\mathrm{N}$ levels were significantly higher in LS compared to MS subplots (78.2 cf. 40.9 $\mathrm{mg} / \mathrm{kg}$ soil, $\mathrm{P}<0.001)$. Mean soil $\mathrm{NH}_{4}-\mathrm{N}$ were not significantly different here but were higher than at Invermay.

In hill country, relatively flat land tends to encourage stock camping behaviour and the subsequent deposition of excreta-N (Bowatte 2003; Gillingham 1982; Gillingham \& During 1973; López et al. 2003; Sakadevan et al. 1993). The nutrient-N in the excreta of grazing animals is a major $\mathrm{N}$-supplement for plant growth (Gillingham 1982). We observed a significantly greater number of dung deposits on LS compared to MS subplots for the combined data set $(\mathrm{P}<0.05$, Table 4). This observation and the findings discussed above suggests that the non-uniform deposition of excreta- $\mathrm{N}$ at Ballantrae resulted in the development of nitrification 'hotspots' on the micro relief areas within experimental plots, regardless of the rate of fertiliser-N. An interaction between the number of dung deposits and soil $\mathrm{pH}$ may also be a possibility, as the significantly higher number of dung deposits on LS compared to MS sites coincides with higher $\mathrm{pH}$ values (Tables $2 \& 4$ ). However this interaction was not included in the analysis.

The purpose of the present study was to investigate how high inputs of fertiliser- and excreta- $\mathrm{N}$ affected the $\mathrm{NP}$ of hill country soils at two locations. In particular, results demonstrated that $\mathrm{NP}$ and $\mathrm{NO}_{3}-\mathrm{N}$ is higher in camp sites than on medium slopes at Ballantrae, and that these increased with $\mathrm{N}$ fertiliser application rate at Invermay. The greater $\mathrm{NP}$ and $\mathrm{NO}_{3}-\mathrm{N}$ in camp sites was probably influenced by the fact that a significantly greater amount of excreta, and therefore greater amount of substrate $\mathrm{NH}_{4}-\mathrm{N}$ was available for nitrification within these subplots. Higher rates of nitrification in camp areas and high $\mathrm{N}$ treatments have the potential to increase losses through nitrate leaching and denitrification. The fact that application of high rates of $\mathrm{N}$ fertiliser over the previous 18 months did not increase NP at Ballantrae should be noted, as it suggests that potential losses may be lower at Ballantrae than Invermay.

More work is required to identify the reason for the lower NP at Ballantrae. As indicated earlier, soil pH is one possible reason, but there may be others such as wide $\mathrm{C}: \mathrm{N}$ ratios in hill soils, and thus high $\mathrm{N}$ retention, soil mineral type or climatic restrictions as suggested by Bowatte (2003), Lambert et al. (1982), Sakadevan et al. (1993), Sarathchandra (1978) and Steele et al. (1980).
Future work should also include specific leachate and nitrous oxide measurements within these sites to indicate threshold NP rates for $\mathrm{N}$ losses via leaching and denitrification. Leachate measurements have been made at both sites according to $\mathrm{N}$ fertiliser treatment, but not between camp and non-camp sites. Both unpublished Invermay and Ballantrae data sets detected significant increases of $\mathrm{NO}_{3}-\mathrm{N}$ in leachate collected from the $500 \mathrm{~N}$ fertiliser paddocks compared to $0 \mathrm{~N}$ (C. Hoogendoorn \& D. Stevens pers. comm.).

An understanding of how site-specific conditions in hill country situations may influence nitrification activity and the risk of $\mathrm{NO}_{3}-\mathrm{N}$ pollution via leaching and denitrification has the potential to improve the efficiency and profitability of hill country farmland. Nitrification potential in hill country is evidently influenced by both stock and pastoral management practices. Best management practices for fertiliser application in hill country should consider avoiding areas of high NP (i.e. camp sites) in an effort to minimise N-losses via leaching and denitrification.

\section{ACKNOWLEDGEMENTS}

The assistance of the Invermay and Ballantrae field staff in carrying out this work is greatly appreciated. Also inputs from reviewers. Authors thank Massey University and AgResearch Limited for providing funding for this research.

\section{REFERENCES}

Ball, R.P.; Luscombe, P.C.; Grant, D.A. 1982. Nitrogen in hill country. pp. 133-148. In: Nitrogen Fertilisers in New Zealand Agriculture. Eds. Lynch, P. B. Ray Richards Publisher, Auckland.

Bowatte, S. 2003. Urine nitrogen in hill country pasture soils. PhD Thesis. Massey University, Palmerston North.

Carran, R.A.; Theobald, P.W.; Evans, J.P. 1995. Emission of nitrous oxide from some grazed pasture soils in New Zealand. Australian Journal of Soil Research 33: 341.

de Klein, C.A.M.; van Logtestijn, R.S.P. 1994. Denitrification and $\mathrm{N}_{2} \mathrm{O}$ emission from urine-affected grassland soil. Plant and Soil 163: 235-242.

Di, H.J.; Cameron, K.C. 2002. The use of a nitrification inhibitor, dicyandiamide (DCD), to decrease nitrate leaching and nitrous oxide emissions in a simulated grazed and irrigated grassland. Soil Use and Management 18: 395-403.

Fair, R.J.; Jamieson, H.M.; Hopkins, D.W. 1994. Spatial distribution of nitrifying (ammonium-oxidizing) bacteria in soil. Letters in Applied Microbiology 18: 162-164.

Field, T.R.O.; Ball, R.P.; Theobald, P.W. 1985. Leaching 
of nitrate from sheep-grazed pastures. Proceedings of the New Zealand Grassland Association 46: 209-214.

GenStat 2006. GenStat for Windows. VSN International Ltd, Oxford. pp.

Gillingham, A.G. 1982. Topographic and management effects on dung distribution by grazing sheep. Proceedings of the New Zealand Grassland Association 43: 161-170.

Gillingham, A.G.; During, C. 1973. Pasture production and transfer of fertility within a long-established hill pasture. New Zealand Journal of Experimental Agriculture 1: 227.

Hart, S.C.; Stark, J.M.; Davidson, E.A.; Firestone, M.K. 1994. Nitrogen mineralisation, immobilisation, and nitrification. pp. 985-1018. In: Methods of Soil Analysis Part 2. Eds. Bigham, J. M.; Mickelson, S. H. Soil Science Society of America Book Series, Wisconsin.

Hatch, D.J.; Bhogal, A.; Lovell, R.D.; Shepherd, M.A.; Jarvis, S.C. 2000. Comparison of different methodologies for field measurement of net nitrogen mineralization in pasture soils under different soil conditions. Biology and Fertility of Soils 32: 287-293.

Haynes, R.J. 1986. Mineral Nitrogen in the Plant-Soil System. Academic Press, Inc, Sydney. 483 pp.

Haynes, R.J.; Williams, P.H. 1992. Changes in soil solution composition and $\mathrm{pH}$ in urine-affected areas of pasture. Journal of Soil Science 43: 323-334.

Hewitt, A.E. 1998. New Zealand Soil Classification. Landcare Research Ltd, New Zealand, Lincoln. 133 pp.

Kemmit, S.J.; Wright, D.; Goulding, K.W.T.; Jones, D.L. 2006. $\mathrm{pH}$ regulation of carbon and nitrogen dynamics in two agricultural soils. Soil Biology \& Biochemistry 38: 898-991.

Lambert, M.G.; Mackay, A.D.; DeVantier, B.P.; McDougall, D.B.; Barker, D.J.; Park-NG, Z.A. 2003. Redefining the production potential of hill pastures using fertiliser nitrogen. New Zealand Grasslands Association 65: 35-40.

López, I.F.; Hodgson, J.; Hedderley, D.I.; Valentine, I.; Lambert, M.G. 2003. Selective defoliation by sheep according to slope and plant species in the hill country of New Zealand. Grass and Forage Science 58: 339.
Morton, J.D.; Korte, C.J.; Smith, D.R.; Watt, B.D.; Smith, R.G. 1993. Nitrogen use and farm performance on Wairarapa sheep and beef farms. New Zealand Grasslands Association 55: 54-56.

Otago Regional Council 2006. GrowOTAGO climate and soil data. Online Database.

Radcliffe, J.E. 1982. Effects of aspect and topography on pasture production in hill country. New Zealand Journal of Agricultural Research 25: 485.

Saggar, S.; Bolan, N.S.; Bhandral, R.; Hedley, C.B.; Luo, J. 2004. A review of emissions of methane, ammonia, and nitrous oxide from animal excreta deposition and farm effluent application in grazed pastures. New Zealand Journal of Agricultural Research 47: 513-544.

Sakadevan, K.; Hedley, M.J.; Mackay, A.D. 1993. Mineralisation and fate of soil sulphur and nitrogen in hill pastures. New Zealand Journal of Agricultural Research 36: 271-281.

Sarathchandra, S.U. 1978. Nitrification activities of some New Zealand soils and the effect of some clay types on nitrification. New Zealand Journal of Agricultural Research 21: 615-621.

Sarathchandra, S.U.; Perrott, K.W.; Upsdell, M.P. 1984. Microbiological and biochemical characteristics of a range of New Zealand soils under established pasture. Soil Biology \& Biochemistry 16: 177-183.

Schall, R. 1991. Estimation in generalized linear models with random effects. Biometrika 78: 719-727.

Steele, K.W.; Wilson, A.T.; Saunders, W.M.H. 1980. Nitrification activity in New Zealand grassland soils. New Zealand Journal of Agricultural Research 23: 249-256.

Steenvoorden, J.H.A.M.; Fonck, H.; Oosterom, H.P. 1986. Losses of nitrogen from intensive grassland systems by leaching and surface runoff. pp. 85-98. In: Nitrogen Fluxes in Intensive Grassland Systems. Eds. Van der Meer, H. G.; Ryden, J. C.; Ennik, G. C. Martinus Nijhoff Publishers, Dordrecht.

Taylor, J. 1973. The analysis of designed experiments with censored observations. Biometrics 29: 35-43.

Whitehead, D.C. 1995. Grassland Nitrogen. CAB International, Wallingford. $397 \mathrm{pp}$. 